\title{
Impact of Interest Rate Spread on Profitability in Nepalese Commercial Banks
}

\author{
Chitra Bahadur Karki \\ Lecturer \\ Faculty of Management, Mahendra Multiple Campus, Dharan, Tribhuvan University, Nepal \\ Email: chitrakarki853@gmail.com
}

DOI: https://doi.org/10.3126/dristikon.v10i1.34543

\begin{abstract}
The paper aims to examine the relationship between interest rate spread (IRS) and profitability and the impact of IRS on profitability of commercial banks in Nepal. Secondary data have been collected from the annual reports of Nepal investment bank ltd. from fiscal year 2066/67to 2075/76. A regression technique has been used considering statistical package Minitab 16 version to analyze the data. The study reveals the positive impact of IRS upon the profitability of Nepal investment bank ltd. This study provides sufficient evidences to Nepalese commercial banks about the impact of their IRS on their profitability. The result of this study motivates to Nepalese commercial banks to understand the importance of IRS to raise profitability. Based on the findings, the study is useful to Nepalese commercial banks for making balance between deposit rate and lending rate and maintaining optimum level of interest rate spread to attract both depositors and debtors. This study is also useful to new researchers as a reference for conducting study on similar topic.
\end{abstract}

Keywords: interest rate spread, profitability, commercial bank, ROA, ROE

\section{Introduction}

\subsection{Background}

Banking sector of Nepal has revealed being very large and potential over the years. Commercial bank occupies larger space in banking and financial institutions industry in Nepalese economy. Commercial banks play important roles in the financial system in Nepal. There is a considerable expansion in the profitability of banking sector demonstrated by performance and stability indicators. For the stability of commercial bank there should be sound profit margin. Higher interest rate spread (IRS) is the most important factor for the sound profit margin. The difference between lending and deposit interest rate is known as interest rate spread. Interest rate spreads directly impact on profitability of financial institution. No doubt, higher interest spread rate increases the profitability and vice-versa.

Commercial banks can increase their profit margins through higher lending rates and lower deposit rates. But Banks do not charge too low rate on loan because the revenue from the interest income will not be enough to cover the costs. On the other hand, they cannot charge too high loan rates because they will not be able to keep the banking 
relationship with the borrowers. Thus, determination of the appropriate lending rates usually becomes a major issue in banking industry (Poudel, 2018, p.12).

When the interest rates to depositor's decrease interest rate spread increases then it will discourage the savings and on the other hand, if interest rate to depositor increases then it will badly affect the investment. Commercial banks usually employ their investment at a higher interest rate compared to the interest rate they apply on deposits. Various studies have been conducted till now to explain the empirical association between interest rate spread and profitability of commercial banks but the findings are not symmetrical. The study focuses the impact of interest rate spread on Nepalese commercial bank's profitability by using regression techniques.

\subsection{Research Problem}

The focus of this study is to find out the impact of interest rate changes on the profitability in the context of Nepal by taking one listed commercial bank. Interest rate spread and indicators of profitability such as return on assets (ROA), return on equity (ROE)are discussed and examined to reflect practical scenario. The specific problems are as follows:

- What is the relationship between interest rate spread and profitability?

- What is the impact of interest rate spread on profitability of concern?

- What does the regression analysis say about the relationship between the two variables?

\subsection{Research Objective}

The general objective of the study is to determine the impact of interest spread rate on profitability of commercial banks in Nepal. The specific objectives of the study are as follows:

- To identify the relationship between interest rate spread and profitability.

- To analyze the impact of interest rate spread on profitability of concern.

- To examine regression analysis between two variables.

\subsection{Rationale of the Study}

The significance of this research article is to identify, analyze and interpret portion of impact on profitability of the interest spread rate of bank. This research article will also help bankers to analyze the past impact of interest rate spread and its impact on profitability. Other significances of this research article are as follows:

- This study will be useful to identify the level of impact of interest rate spread on profitability of leading commercial banks of Nepal. 
- This study will be useful for commercial banks to carry out necessary steps to determine appropriate lending and deposit rate.

- Similarly, this study will be useful for new researchers to learn more about the interest rate and profitability of commercial banks in Nepal.

\subsection{Limitations of the Study}

The study is limited to the following constraints:

- The study focuses the relationship between interest rate spread and profitability only.

- The study is based on secondary data; the results depend upon the reliability and validity of data.

- Most of the data were collected from online and the coverage period is from FY 2066/2067 to FY 2075/2076 B.S.

- Only one commercial bank is taken as sample

\subsection{Literatures Review}

This section presents the review of related literature in order to establish a basis for the investigation of the impact of interest rate spread on the profitability in Nepalese commercial banks. The review covered previous empirical studies conducted in various countries on this subject.

Khan (2014) focused his study to identify the impact of interest rate changes on the profitability. The objective of this study is to find out the relationship between interest rate and commercial bank's profitability in Pakistan by examining the financial statements of four major banks during 2008 to 2012. Secondary data was used in this research. Official websites of commercial banks and from the official website of State Bank of Pakistan were used for the source of data collection. In this study interest rate is an independent variable and bank profitability is a dependent variable to examine the impact of interest rate changes on the profitability. Pearson correlation method is used in this study. This study found that interest income of bank is considerably affected by interest rate. It means profitability of bank is dependent on the interest rate.

Noreen et al. (2018) conducted a research on the impact of interest rate changes on the profitability. The objective of this study is to check the relationship among interest rate and banks profitability. Secondary data was used in this research. In this research data collected from the bank's annual reports from 2007 to 2018. In this study the bank's profitability is dependent and interest rate is independent variable. The Pearson correlation Process is used to examine the relationship among interest rate and bank's profitability. This study found that, there is optimistic and direct relationship among interest rate and banks profitability. When the 
banks charged high interest rate from their customers then they obtain higher profitability and vice versa.

Jui et al. (2020) carried out a research to examine the association between interest rate changes and profitability. The objective of this research is to establish and explain the association between interest rate and profitability and also to analyze the cause and effect relationship between two stated issues by using the comparative data of several consecutive years of commercial banks in Bangladesh. The secondary data was used and collected from annual reports of all the 30 listed commercial banks of Bangladesh by using 5 consecutive years' data (2014-2018). In this research, interest rate spread is taken as independent variable and ROE, ROA, NIM (Net Interest Margin) were used as dependent variables for reflecting profitability measures. In this research multiple linear regression model is used to reflect the relationship among these variables. Finding of this research is that, there is a positive relation between interest rate and profitability of commercial banks.

Cecilia and Mouni (2016) conducted a study on influence of interest rates on the performance of commercial banks. The general objective of this study was to investigate the influence of interest rates determinants on the performance of commercial banks in Kenya. The target population of the study was all 43 commercial banks operating in Kenya. The sample size was 26 commercial banks obtained from the population. Multiple regression analysis was used in this research to analyze the data. This research found that higher levels of discount rates, inflation rates and exchange rates lead to higher performance in commercial banks in Kenya, higher levels of reserve requirement ratio result in lower bank performance in Kenya.

Poudel (2018) conducted a research on impact of interest rate spread on profitability. Main objective of this research is to determine the impact of interest spread rate on profitability of commercial banks in Nepal. This study is based on the descriptive research design that uses secondary data. Data are collected from audited annual reports of concern banks. In `this research, weighted average interest rate spread is taken as independent variable and ROA, and NPM were used as dependent variables for reflecting profitability measures. Analysis is carried out by using simple regression model and descriptive statistics tools in this research. This research found that there is positive relationship between interest rate spread and profitability of commercial banks in Nepal.

Khan et al. (2014) carried out a research to examine the effect ofinterest on bank's profitability. The objective of this study is to check and examine the market interest rate effect on the bank's profitability in public and private sectors of Pakistan. Interest rate is used as independent variable and profitability is used as dependent variable. Bank lending rates were taken as a proxy for interest rate while ROA and ROE were taken as a profitability of the banks. The regression model was used in the study to witness the effects of interest rate on 
profitability. Finding of this research is that the interest rate has more effects on both ROA and ROE in private banks as compared to the public sector banks.

Oywoki et al. (2020) made an investigation on market interest rate and profitability. Main objective of this research is to examine the effect of nominal interest rate on profitability of listed commercial banks within Kenya. The secondary data was used and collected from secondary sources which were attained from the content of financial reports of 11 banks quoted at NSE. In this research ROA was used as proxy for profitability measure and reflects the dependent variable and nominal interest rate, real interest rate, interbank rate plus bank size were used as independent variables. Autoregressive distributed lag models were used in this research to identify how market interest rate influenced revenue of listed commercial banks within Kenya. This research found that there was significant positive relationship with real, nominal, interbank and bank size with ROA.

\subsection{Research Gap}

Although many research works related to interest rate and profitability of commercial banks are found in the literature, very few research papers are found related to interest rate and profitability of commercial banks in the Nepalese context and there is still lack of latest research and article in the Nepalese context. One review research seems to be same work but the relevant information was taken only up to 2073/74 B.S. This research is related to Nepalese context by taking latest data (up to 2075/76 B.S.) available in annual report of Nepal investment bank, so this research will help to fill research gap.

\section{Methods and Materials}

The study examined the impact of interest rate spread on the profitability of the Nepal investment bank ltd. using secondary data collected from the annual reports of Nepal investment bank ltd. The study employed regression analysis technique and descriptive statistics using the computer software Minitab 16 version to examine the relation between interest rate spread and profitability of the Nepal investment bank. IRS were identified and employed as the independent variables while ROA and ROE were employed as indicator for profitability were used as dependent variables of Nepal investment bank ltd. Relevant information were obtained from the annual report of Nepal investment bank ltd. of 10 years i.e. fiscal year 2066/67to 2075/76 B.S.

\section{Model}

Independent variable Dependent variables

Interest Rate Spread

ROA, ROE 


\section{Results and Discussion}

\subsection{Data Presentation and Discussion}

The study focuses to examine the impact of weighted average interest rate spread on return on assets and return on equity. Table 1 is summarized aggregate values of the variables.

\section{Table 1}

Data Collection Sheet

\begin{tabular}{|c|c|c|c|}
\hline Year & IRS $(\%)$ & ROA $(\%)$ & ROE $(\%)$ \\
\hline $2066 / 67$ & 4.4 & 2.2 & 28 \\
\hline $2067 / 68$ & 4.1 & 2 & 25.7 \\
\hline $2068 / 69$ & 4.5 & 1.6 & 20.1 \\
\hline $2069 / 70$ & 5.5 & 2.6 & 31.7 \\
\hline $2070 / 71$ & 4.8 & 2.3 & 24.5 \\
\hline $2071 / 72$ & 4.6 & 1.9 & 20 \\
\hline $2072 / 73$ & 4.7 & 2 & 15.7 \\
\hline $2073 / 74$ & 4.3 & 2.1 & 16.7 \\
\hline $2074 / 75$ & 4.3 & 2.1 & 14.7 \\
\hline $2075 / 76$ & 4.3 & 1.8 & 13 \\
\hline
\end{tabular}

Note. Annual financial Report of Nepal Investment Bank ltd.,2066/67 to2075/76.

The highest ROA and ROE were recorded in the year 2069/70 with ROA of $2.6 \%$ and ROE 31.7 and the lowest ROA in 2068/69 with 1.6\%, ROE in 2075/76 with 13\% for the period covered. It can also be observed that the profitability nature has not been steady, going up and down over the period. This should be due to the changing nature of the independent variables with interest rate spread also exhibiting the same characteristic. A summary of the Descriptive statistics results is presented in table 2.

Table 2

Descriptive Statistics: IRS, ROA, ROE

\begin{tabular}{cccccccc}
\hline Variables & $\mathrm{N}$ & Mean & S. Dev. & Variance & Coef.Var. & Minimum & Maximum \\
\hline IRS & 10 & 4.550 & 0.395 & 0.156 & 8.68 & 4.1 & 5.5 \\
ROA & 10 & 2.0600 & 0.2757 & 0.0760 & 13.3800 & 1.6000 & 2.6000 \\
ROE & 10 & 21.01 & 6.24 & 38.88 & 29.68 & 13.00 & 31.70 \\
\hline
\end{tabular}

Note. Author's calculation using Mini Tab.

The following observations can be made from the table 2 which was prepared on the basis of 10 year's data. 
- The ROA of the bank range between 2.6 and 1.6 with mean 2.06 and standard deviation 0.2757 indicating low variance

- The ROE of the bank range between 31.7 and 13 with mean 21.06 and standard deviation 6.24 indicating high variance.

- IRS range between 5.5 and 4.1 with mean 4.55 and standard deviation 0.395 indicates normal variability.

From the above analysis found that there is high, low, and normal variance of selected variables as their standard deviation. The low variance is normally related with effective assets management, high variance is related with variance of shareholder's fund and normal variance is related with reasonable interest rate.

\section{Table 3}

General Regression Analysis: ROA versus IRS

The regression equation

\begin{tabular}{lcccc}
\multicolumn{2}{c}{ ROA $=0.020+0.448$ IRS } \\
Predictor & Coef & SE Coef. & T & P \\
\hline Constant & 0.0198 & 0.8629 & 0.02 & 0.982 \\
IRS & 0.4484 & 0.1890 & 2.37 & 0.045 \\
\hline
\end{tabular}

Note. Summary of Model.

$$
\begin{array}{lll}
\mathrm{S}=0.224028 & \mathrm{R}-\mathrm{Sq}=41.3 \% & \mathrm{R}-\mathrm{Sq} \text { (adj. })=34.0 \% \\
\mathrm{~F}=5.63 & \mathrm{P}=0.04 &
\end{array}
$$

The table 3 shows the summary of the regression results of the IRS and their effect on ROA of Nepal investment bank ltd. The results show that ROA significantly positive on IRS of Nepal investment Bank Ltd. The explanatory power of the model as informed by R-Sq $41.3 \%$ is positively and statistically significant given the high value of the F- statistics 5.63. This indicates that the model is a very good fit and independent variable influenced the dependent variable. The relatively high adjusted $\mathrm{R}^{2}$ of $34.0 \%$ shows that the regression model fits the data well. The study also shows that the calculated $\mathrm{F}$ statistics value 5.63 is significant at $5 \%$ level of significance as P-value $0.045<0.05$. A unit increase or decrease in IRS would lead to an increase or decrease in ROA of Nepal investment bank ltd. with a margin 0.4484 . This indicates a significant relation between the IRS and ROA of Nepal investment bank ltd.

The table 4 shows the summary of the regression results of the IRS and their effect on ROE of Nepal investment bank ltd. The results show that ROE significantly positive on IRS of Nepal investment bank ltd. The explanatory power of the model as informed by R-Sq $28.0 \%$ is 
positively and statistically significant given the high value of the F- statistics 3.11 . This indicates that the model is a very good fit and independent variable influenced the dependent variable. The relatively high adjusted $\mathrm{R}^{2}$ of $19.0 \%$ shows that the regression model fits the data well.

\section{Table 4}

General Regression Analysis: ROE versus IRS

The regression equation

$$
\text { ROE }=-17+8.35 \text { IRS }
$$

\begin{tabular}{ccccc}
\hline Predictor & Coef. & SE Coef. & T & P \\
\hline Constant & -16.96 & 21.62 & -0.78 & 0.455 \\
IRS & 8.345 & 4.736 & 1.76 & 0.116 \\
\hline
\end{tabular}

Note. Summary of Model

$$
\begin{aligned}
& \mathrm{S}=5.6131 \mathrm{R}-\mathrm{Sq}=28.0 \% \quad \mathrm{R}-\mathrm{Sq}(\operatorname{adj} .)=19.0 \% \\
& \mathrm{~F}=3.11 \quad \mathrm{P}=0.116
\end{aligned}
$$

The study also shows that the calculated F statistics value 3.11 with p-value 0.116 ; imply that there is very significant relationship between the IRS and ROE. A unit increase or decrease in IRS would lead to an increase or decrease in ROE of Nepal investment bank ltd. This indicates a significant relation between the IRS and ROE of Nepal investment bank ltd. This research has a similar result with previous studies on concern topic.

\subsection{Findings}

Thus, from the above results and discussion the findings are as follows:

- There is significant relationship between interest rate spread and profitability.

- There is a direct impact of IRS on profitability (ROA, ROE).

- The regression equation between two variables: $\mathrm{ROE}=-17+8.35 \mathrm{IRS}$ and $\mathrm{ROA}=0.020$ +0.448 IRS

\section{Conclusion}

The basic purpose of this study is to examine the impact of interest rate spread on the profitability of Nepal investment bank ltd. The interest rate spread was regressed against profitability proxy by ROA and ROE. Secondary data was collected from the annual reports of Nepal investment bank ltd. from 2066/67 to 2075/76.General regression model was adopted to determine relationship between interest rate spread and profitability of Nepal investment bank ltd. By studying the weighted average IRS, ROA and ROE of sample bank, the minimum IRS was $4.1 \%$ and maximum was $5.5 \%$, the minimum ROA was $1.6 \%$ and maximum was $2.6 \%$ and minimum ROE was $13 \%$ and maximum was $31.7 \%$. This indicates that weighted average IRS, ROA and ROE are changing over the time. The study shows that the bank's profitability 
affected by IRS. When interest rate spread increases, it will lead to increase profitability, i.e. increase in return on equity, return on assets and vice versa. The study concluded that there is optimistic and direct relationship between interest rate spread and bank's profitability.

Based on the findings, this study is useful to Nepalese commercial banks formaking balance between deposit rate and lending rate and maintaining optimum level of interest rate spread to attract both depositors and debtor. This study is also implacable tonew researchers as a reference for conducting study on similar topic.

\section{References}

Jui, S.N., Sakib, R.H., \& Rafsan, M. A. (2020). Association between interest rate changes and profitability of commercial banks of Bangladesh. International Journal of Science and Business, 4(9), 17-37. http://dx.doi.org/10.5281/zenodo.3965681

Khan, W.A. (2014). Impact of interest rate changes on the profitability of four major commercial banks in Pakistan. International Journal of Accounting and Financial Reporting, 4(1), 142-154. http://dx.doi.org/10.5296/

Maigua, C., \& Mouni, G. (2016). influence of interest rates determinants on the performance of commercial banks in Kenya. International Journal of Academic Research in Accounting, Finance and Management Sciences, 6(2),121-133. http://dx.doi.org/10.6007/IJARAFMS/v6-i2/2078

Malik, M.F., Khan, S., Khan, M.L., \& Khan, F. (2014). Interest rate and its effect on bank's profitability. Journal of Applied Environmental and Biological Sciences, 4(8), 225-229. http://www.textroad.com/

Naceur, B. S., \&Goaied, M. (2008). The determinants of commercial bank interest margin and profitability: Evidence from Tunisia. Frontiers in Finance and Economics, 5(1),106 130. http://ssrn.com/abstract $=1538810$

Noreen, S., Liaqat, A., \& Parveen, F. (2018). Interest rate changes and its impact on the profitability of Pakistani commercial banks. International Journal of Academic Research in Business and Social Sciences, 8(12), 948-954. http://dx.doi.org/10.6007/IJARBSS/v8-i12/5088

Oywoki, D. R., Muganda, M., \& Ondiek, A. (2020). Market interest rate and profitability of listed commercial banks in Kenya. International Journal of Multidisciplinary and Current Research, 8(2), 261-271. https://doi.org/10.14741/ijmcr/v.8.2.16

Poudel, P. (2018). Impact of interest rate spread on profitability of commercial banks in Nepal. [Unpublished Master Degree Thesis), Patan Multiple Campus, Tribhuvan University Nepal

Shuremo, G.A. (2016). Determinants of banks' profitability: Evidence from banking industry in Ethiopia. International Journal of Economics, Commerce and Management,4(2),442463. http://ijecm.co.uk/

Were, M., \&Wambua, J. (2014). What factors drive interest rate spread of commercial banks? Empirical evidence from Kenya. Review of Development Finance,4(2),73-82. https://doi.org/10.1016/j.rdf.2014.05.005 